\title{
Kontribusi dan Peran KH. Hasyim Asy'ari dalam Membingkai Moderasi Beragama Berlandaskan al Quran dan Hadis di Indonesia
}

\author{
Umma Farida \\ Institut Agama Islam Negeri Kudus, Indonesia \\ ummafarida@iainkudus.ac.id
}

\begin{abstract}
This article aims to reveal the ideas of Kiai Hasyim Asy'ari in knitting the unity and framing the religious moderation based on the Quran and Hadith in Indonesia. His role is still relevant to study considering the life of Indonesian people until now still often confront and even contradict between religion and culture. Besides, the dichotomy between traditionalist and modernist Islam has strengthened once again in the internal circles of Muslims, which if it was not immediately found a solution, it can lead to divisions between them. This study uses qualitative methods and data collection uses documentation techniques to be analyzed descriptively-critically. This research shows that Kiai Hasyim Asy'ari played a significant role in uniting Muslims in particular and Indonesian society in general. He taught Islam by emphasizing the formation of character, politeness, gentleness, and moderate understanding of Islam as stated in his book Risalah Ahl as-Sunnah wa al-Jama'ah. He also called for doing good to others despite being of different religions, loving the Prophet, and making unity, brotherhood, and tolerance as the foundation of moderation between religious communities in Indonesia.
\end{abstract}

Keywords: Brotherhood, moderation, religion, tolerance, unity

\begin{abstract}
Abstrak
Artikel ini bertujuan untuk menguak gagasan dan ide KH. Hasyim Asy'ari (Kiai Hasyim) dalam merajut persatuan dan membingkai moderasi beragama berlandaskan al Quran dan Hadis di Indonesia. Pemikiran Kiai Hasyim masih tetap relevan untuk dikaji mengingat kehidupan masyarakat Indonesia hingga saat ini masih sering memperhadap-hadapkan bahkan mempertentangkan
\end{abstract}


antara agama dan budaya. Selain itu, dikotomi antara Islam tradisionalis dan modernis kembali menguat di kalangan internal umat Islam yang apabila tidak segera dicarikan solusinya maka dapat mengakibatkan perpecahan di antara mereka. Kajian ini menggunakan metode kualitatif dan pengumpulan datanya menggunakan teknik dokumentasi untuk selanjutnya dianalisis secara deskriptif-kritis. Penelitian ini menunjukkan bahwa Kiai Hasyim Asy'ari berperan dalam mempersatukan umat Islam khususnya dan masyarakat Indonesia pada umumnya. Ia mengajarkan Islam dengan menekankan pada pembentukan karakter, kelembutan, kesantunan, dan pemahaman Islam yang moderat sebagaimana tertuang dalam bukunya Risalah Ahl as-Sunnah wa alJama'ah. Ia juga menyeru untuk berbuat kebaikan kepada orang lain meskipun berbeda agama, mencintai Rasulullah Saw., dan menjadikan persatuan, persaudaraan, dan toleransi sebagai landasan moderasi antar umat beragama di Indonesia.

Kata kunci: Agama, moderasi, persatuan, persaudaraan, toleransi

\section{Pendahuluan}

Keragaman dalam kehidupan merupakan suatu keniscayaan yang dikehendaki Allah Swt. Secara kodrati, keberadaannya tidak dapat disangkal dan dipungkiri terjadi di seluruh dunia, termasuk Indonesia, yang secara nyata telah ditakdirkan menjadi bangsa yang terdiri dari berbagai suku, adat istiadat, budaya dan agama QS. Al-Hujurat: 13. Dalam menciptakan keharmonisan hidup yang plural, bangsa Indonesia telah melakukan berbagai upaya yang secara garis besar dapat dikelompokkan menjadi dua: Pertama, upaya konstitusional dan politik, seperti dalam penetapan undang-undang, peraturan, dan sejumlah petunjuk mengenai penataan pluralitas itu. Kedua, membangun ketulusan pluralitas melalui penumbuhan kesadaran titik temu (kalimatun sawa') di tingkat esoterik agama-agama secara tulus (Harahap, 2011: 6).

Upaya untuk menumbuhkan titik temu antara agama-agama mengharuskan masing-masing pemeluk agama untuk bisa bersikap moderat dan menghindari ekstrimisme (Kasdi, 2019: 181). Peran tokoh agama, dalam hal ini Kiai, tidak bisa dinafikan, karena merekalah yang telah banyak berjuang mengajarkan moderatisme beragama dengan melandaskan pada sumber ajaran Islam yang hakiki, al Quran dan Hadis, serta menanamkan sikap moderat tersebut kepada para santri dan anak didiknya. Kiai Hasyim Asy'ari adalah satu di antara kiai yang tidak hanya berperan dalam proses perintisan kemerdekaan Indonesia saja, melainkan juga berkontribusi dalam smenciptakan keharmonisan hidup beragama di Indonesia (Syihab, 1994: 810). 
Kiai Hasyim merupakan sosok penting yang berpengaruh bagi masyarakat muslim Indonesia, minimal dikarenakan dua hal: Pertama, Kiai Hasyim merupakan ulama yang secara konsisten mengusung paham Ahlussunnah wal Jamaah, yaitu paham keagamaan yang berpegang pada teologi Asy'ariyah dan Maturidiyah dalam bidang Aqidah, mengacu pada empat madzhab dalam bidang fiqh yakni Madzhab Hanafi, Maliki, Syafi'i, dan Hanbali, serta berpedoman pada Imam al-Ghazali dan Imam Junaid alBaghdadi dalam bidang Tasawuf. Paham Ahlussunnah wal Jamaah merupakan paham yang dianut oleh mayoritas masyarakat muslim tidak hanya di Indonesia saja, melainkan juga di seluruh dunia. Kiai Hasyim berusaha mensosialisasikan paham tersebut, membuka cakrawala umat untuk tidak memandang ajaran al Quran dan hadis secara kaku dan memahaminya secara literal yang kemudian berdampak pada lahirnya sikap ekstrimisme beragama dan klaim kebenaran sepihak. Kiai Hasyim menemukan urgensi pengajaran paham Ahlussunnah wal Jamaah di Indonesia mengingat negara ini memiliki banyak keragaman etnis, suku, agama, budaya, ras, dan sebagainya. Keragaman yang dimiliki Indonesia yang merupakan pemberian Tuhan dapat mengancam persatuan dan kesatuan bangsa jika tidak dikelola dengan baik. Di sini pulalah, Kiai Hasyim berperan menumbuhkan sikap toleransi dan saling menghormati di antara umat beragama di Indonesia, dengan berpijak dari sumber ajaran agamanya yakni al Quran dan Hadis.

Kedua, Kiai Hasyim merupakan pendiri organisasi sosial-keagamaan terbesar di tanah air, Nahdlatul Ulama (NU). Sejak berdirinya bahkan hingga sekarang, NU merupakan salah satu organisasi yang memiliki paham keagamaan yang moderat berlandaskan Ahlussunnah wal Jamaah. Melalui organisasi yang didirikannya, Kiai Hasyim telah menyelamatkan bangsa dari radikalisme, ekstrimisme dan terorisme. Pada saat yang sama, Kiai Hasyim tidak pernah mempertentangkan antara keindonesiaan dengan keislaman. Di samping itu, Kiai Hasyim juga telah menginspirasi banyak pihak agar berjuang dalam ranah pendidikan umat, menjadikan Islam sebagai kekuatan konstruktif, dan menanamkan paham Ahlussunnah wal Jamaah sebagai salah satu pondasi untuk pengembangan umat yang toleran, moderat, dan adil tanpa kehilangan identitas keislamannya (Misrawi, 2013: 5-13).

Berpijak pada uraian di atas, maka menguak gagasan dan ide Kiai Hasyim Asy'ari dalam merajut persatuan dan membingkai moderasi beragama berlandaskan al Quran dan Hadis di Indonesia menjadi penting. Pemikiran Kiai Hasyim masih tetap relevan untuk dikaji mengingat kehidupan masyarakat 
Indonesia hingga saat ini masih sering mempertentangkan antara agama dan budaya. Demikian pula, adanya dikotomi antara Islam tradisionalis dan modernis semakin memperlebar potensi perpecahan di kalangan internal umat Islam yang harus segera dicarikan solusinya.

\section{Metode}

Kajian ini hendak mengurai gagasan dan ide Kiai Hasyim dalam merajut persatuan dan membingkai moderasi beragama berlandaskan al Quran dan Hadis di Indonesia. Kajian ini menggunakan metode kualitatif dan pengumpulan datanya menggunakan teknik dokumentasi untuk selanjutnya dianalisis secara deskriptif-kritis. Dalam hal ini, pemikiran Kiai Hasyim terkait moderasi beragama yang berpijak dari al-Qur'an dan Hadis akan dideskripsikan secara utuh baik dari sumber primer ataupun sekunder, disertai dengan analisis kritis terhadap pemikiran Kiai Hasyim tersebut.

\section{Pembahasan}

\section{Mengenal Lebih Dekat Kiai Hasyim Asy'ari}

Kiai Hasyim Asy'ari lahir pada hari Selasa, 14 Februari 1871 di Desa Gedang, Tambakrejo, Jombang, Jawa Timur. Kiai Hasyim dilahirkan dari keluarga religius dan merupakan anak ketiga dari sebelas bersaudara. Ayahnya, Kiai Asy'ari, merupakan salah satu ulama kharismatik asal Demak, Jawa Tengah. Ibunya bernama Halimah, seorang perempuan yang taat beribadah dan rajin berpuasa selama tiga tahun berturut-turut. Kiai Hasyim berada di kandungan ibunya selama 14 bulan, yang menurut masyarakat Jawa, ini merupakan petanda bahwa kelak ia menjadi tokoh besar di kemudian hari (Hadzik, 2000: 15).

Kiai Hasyim telah memperoleh pendidikan agama sejak kecil. Ia juga telah terbiasa hidup dalam lingkungan pesantren, karena ayahnya merupakan pendiri Pesantren Keras, dan kakeknya dari pihak ibu, Kiai Usman, merupakan pendiri Pesantren Gedang, Jombang. Ketika berusia 13 tahun, Kiai Hasyim sudah dipercaya untuk mendidik para santri di Pesantren Keras yang didirikan oleh ayahnya (Salam, 1966: 32-37).

Meski telah dipercaya untuk mengajar di pesantren ayahnya, namun hal ini tidak menyurutkan niat Kiai Hasyim untuk terus menuntut ilmu. Ketika berusia 15 tahun, ia pun memantapkan hati untuk melakukan pengembaraan ilmiah dengan memperdalam ilmu agama di beberapa pesantren, seperti 
Pesantren Wonorejo Jombang, Pesantren Wonokoyo Probolinggo, Pesantren Langitan Tuban, Pesantren Kademangan Bangkalan Madura, Pesantren Trenggilis Semarang, Pesantren Siwalan Panji Sidoarjo.

Melihat kesantunan dan kematangan ilmu yang dimiliki Kiai Hasyim, maka pengasuh Pesantren Siwalan Panji Sidoarjo, Kiai Ya'qub, meminta Kiai Hasyim menjadi menantunya. Pada tahun 1892, Kiai Hasyim menikah dengan Nyai Khadijah, putri dari Kiai Ya'qub. Pada tahun ini pula, Kiai Hasyim menunaikan ibadah haji sekaligus memperdalam ilmu agama kepada Syaikh Ahmad Khatib al-Minangkabawi dan Syaikh Mahfudh At-Tirmasi, keduanya merupakan Ulama Nusantara yang mengajarkan ilmu agama di Masjid al Haram, Makkah. Disamping juga belajar kepada Syaikh Said al Yamani, Sayyid Sulthan Hasyim al Daghistani, Sayyid Abbas al Maliki, dan Syaikh Abu Bakar Syatha al Dimyati (Burhanuddin, 2011: 324).

Ilmu-ilmu keislaman yang dipelajari Kiai Hasyim adalah: Tauhid, Tafsir, Fiqh dengan konsentrasi pada madzhab Syafi'i, Ulum al-Hadis, Tasawuf, dan gramatika Arab seperti Nahwu, Sharaf, dan Balaghah. Menurut Zainul Milal Bizawie, dari sekian banyak ilmu yang dipelajari, ia lebih banyak memusatkan perhatian dan keahliannya pada hadis, yang dibuktikan dengan sanad keilmuan yang dimiliki Kiai Hasyim yang tersambung pada ulama-ulama hadis terkemuka seperti al-Bukhari dan Muslim (Bizawie, 2016b: 272).

Kompetensi ilmu agama yang dimiliki Kiai Hasyim menjadikannya terpilih menjadi salah satu guru yang mengajar di Masjid al Haram. Kiai Hasyim menetap di Makkah selama tujuh tahun. Pada tahun 1899, kiai Hasyim kembali ke Indonesia dan mendirikan Pesantren Tebuireng. Pesantren ini tidak hanya mengajarkan ilmu agama saja, melainkan juga ketrampilan hidup sehari-hari. Sistem pendidikan yang diinisiasi oleh Kiai Hasyim adalah sistem pengajaran sorogan atau bandongan. Sistem tersebut mengacu pada kitab yang diajarkan. Jika kitab tersebut selesai dikhatamkan, santri dapat melanjutkan ke tingkatan berikutnya (Misrawi, 2013: 66-67).

Pada tahun 1919, pesantren Tebuireng mulai menganut sistem madrasah. Materi yang dikaji semakin meluas dengan adanya penambahan ilmu-ilmu umum seperti Matematika, Bahasa Indonesia, dan Geografi. Menurut Zamakhsyari Dhofier (1994: 82) perkembangan dan kemajuan Pesantren Tebuireng menjadi salah satu lembaga pendidikan yang memiliki pengaruh pada abad ke-20. Di samping mengasuh Pesantren, Kiai Hasyim juga turut angkat senjata berjuang membela negara Indonesia dari cengkeraman 
penjajah Jepang. Pada masa revolusi fisik tahun 1940, kiai Hasyim menyerukan resolusi jihad untuk mengobarkan semangat para santri dan umat Islam dalam berjuang melawan penjajah. Kiai Hasyim pernah ditangkap dan dipenjara oleh Jepang pada tahun 1942 dan tidak lama kemudian ia dibebaskan kembali, dan wafat di Tebuireng Jombang pada tanggal 25 Juli 1947 dalam usia 72 tahun.

\section{Moderasi Pemikiran Keislaman ala Kiai Hasyim}

Pemikiran KH. Hasyim Asy'ari banyak tertuang dalam karya-karyanya, antara lain: al-Qalaid fi Bayani ma Yajib min al-'Aqa'id, al-Risalah alTauhidiyah, Risalah Ahli Sunnah wa al-Jama'ah, al-Risalah fi al-Tasawwuf, Adab al-Alim wa al-Muta'allimin, Ziyadat al-Ta'liqat, al-Tanbihat Al-Wajibat, alRisalat al-Jami'at, al-Nur al-Mubin fi Mahabbah Sayyid al-Mursalin, dan lainnya. Selain itu, pemikiran Kiai Hasyim juga dalam artikel dan kolom yang dimuat di Majalah Nahdlatul Ulama', Panji Masyarakat, dan Swara Nahdlotoel Oelama'.

Ahmad Baso (2017: 121) mengklasifikasikan pemikiran Kiai Hasyim ke dalam lima kategori: Pertama, teologi. Kiai Hasyim menekankan pentingnya Tawhid dalam kehidupan umat Islam. Ia memaknai Tawhid sebagai bentuk pengakuan keimanan seseorang akan keesaan Tuhan, tidak menyekutukanNya dan memohon sesuatu pertolongan hanya kepada-Nya (QS. Al-Fatihah: 5). Kedua, Ahl al-Sunnah wa al-Jama'ah, Kiai Hasyim memegang teguh Hadis Nabi Saw., dan menerima doktrin Ahl al-Sunnah wa al-Jama'ah ini dengan mengikuti salah satu madzhab Sunni (Abu Musa al-Asy'ari dan Abu al-Hasan al-Maturidi), serta menjaga kurikulum pesantren agar sesuai dengan prinsipprinsip Ahlussunnah wal Jama'ah yang berarti mengikuti ajaran nabi Muhammad Saw. dan ujaran ulama. Ketiga, tasawwuf, pemikiran tasawwuf Kiai Hasyim banyak dipengaruhi oleh al-Ghazali dan Abu al-Qasim Junaid alBaghdadi. Kiai Hasyim berusaha memperbaiki akhlak umat Islam dan menyesuaikannya dengan ajaran Islam tanpa bertentangan dengan adat dan budaya masyarakat Indonesia. Keempat, Fiqh, Kiai Hasyim mengikuti salah satu dari mazhab empat yaitu Maliki, Hanafi, Syafi'i, dan Hanbali. Kelima, pemikiran politik. Dalam berpolitik, Kiai Hasyim menyeru umat Islam untuk bersatu, bahwa seluruh rakyat adalah sama di mata hukum, menunaikan hak dan kewajiban masing-masing, menegakkan keadilan, dan mengutamakan kepentingan rakyat.

Menariknya, kata sunnah dalam Ahl al-Sunnah wa al-Jama'ah dalam pandangan Kiai Hasyim tidak terbatas hanya mengikuti sunnah Nabi Saw. dan para sahabat saja, melainkan sunnah yang termasuk di dalamnya jalan para 
ulama yang saleh (Asy'ari, 2011a: 6). Hal ini didasarkan Kiai Hasyim pada hadis Nabi Saw., Hendaklah kalian berpegang teguh pada sunnahku dan para pemimpin setelahku (Abu Dawud, 2005: 12: 211) (Al-Tirmizi, 2006: 9: 287). Adapun kata jama'ah berarti kelompok atau komunitas yaitu, golongan yang mengikuti sunnah Nabi Saw. Dengan demikian, makna Ahl al-Sunnah wa al-Jama'ah mengandung maksud mereka yang berpegang teguh pada sunnah Nabi Saw., para sahabat, serta mengikuti warisan para wali dan ulama (Solikhin, 2016: 348).

Secara spesifik, Salahuddin Wahid dalam Baso (2017: 139-142) menguraikan bahwa konsep Ahl al-Sunnah wa al-Jama'ah dalam pandangan Kiai Hasyim tidak terbatas pada fiqh saja, melainkan konsep itu meliputi akidah, syariat, dan akhlak. Selain itu, Ahl al-Sunnah wa al-Jama'ah juga memiliki lima karakteristik: moderat (Tawassut) (Kasdi, Farida, \& Mahfud, 2020: 57), toleran (Tasamuh), reformatif dan akomodatif (Islah), dinamis (Tathawwur), dan metodologis (Manhaji).

Lima karakteristik ini salah satunya tercermin dalam pemikiran Kiai Hasyim dalam menjaga kearifan Nusantara dengan pertimbangan demi kebaikan umum (Maslahat). Dalam pandangan Kiai Hasyim, sikap yang tidak akomodatif terhadap kearifan Nusantara dapat menghalangi jalannya proses dakwah Islam. Di sini, tampak adanya kesamaan antara metode dakwah yang ditempuh Kiai Hasyim dengan Walisanga. Kiai Hasyim berusaha mencari titik temu antara Islam dan budaya, atau antara hukum syariat dengan hukum adat. Seandainya hukum syari'at mengajarkan ajaran-ajaran normatif agama, maka hukum adat mengajarkan bagaimana hukum agama itu dilaksanakan dalam suasana rukun dan kondusif (Baso et.al, 2017: 18). Oleh karenanya, sikap moderat dan toleran harus selalu dikedepankan termasuk dalam penggunaan dalil, antara dalil yang bertumpu pada teks-teks agama (naqli) dan dalil yang bertumpu pada rasio (aqli), antara pandangan fatalistik dan pendapat yang mengkultuskan kemampuan manusia terutama dalam menghadapi perubahan duniawi.

Moderat juga perlu diapikasikan dalam urusan terkait hukum Islam/ Fiqh sehingga akan membebaskan umat Islam dari ijtihad yang berlebihan dan taklid buta. Di sini, Kiai Hasyim menyerukan pentingnya untuk bermazhab yang bertujuan memudahkan umat Islam dalam memahami teks-teks agama sehingga tidak menjadikan mereka dalam terjebak dalam pemahaman yang literal. Terlebih mayoritas masyarakat Indonesia tidak begitu banyak yang memahami secara baik kosakata dan makna dalam Bahasa Arab. Ciri 
moderatisme pemikiran Kiai Hasyim tampak dalam ketegasan sikapnya dalam memahami dalil-dalil yang pasti (qat'i) dan toleran terhadap dalil-dalil yang zhanni. Termasuk juga moderat dalam menyikapi budaya, ialah mempertahankan budaya lama yang masih baik dan menerima budaya baru yang lebih baik (Solikhin, 2016: 349).

Kiai Hasyim dikenal sebagai ulama dan pendidik yang menanamkan pendidikan karakter kepada para santri dan mengajarkan kemandirian kepada mereka, tidak hanya dalam hal ekonomi dan politik, melainkan juga dalam kebudayaan dan aktifitas ilmiah. Para santri diajari untuk mengenali diri dan membekali diri dengan ilmu pengetahuan khususnya ilmu agama, mereka juga diajarkan untuk menanamkan kebanggaan terhadap tradisi bangsa Indonesia yang tidak berseberangan dengan ajaran Islam, menekankan persatuan di antara sesama bangsa Indonesia dengan tidak membedakan suku, ras, agama, dan etnis. Pada saat yang sama, Kiai Hasyim juga mengajak para ulama menjadi pelopor perdamaian jika ada perselisihan di antara rakyat Indonesia, bukan justru malah memperkeruh perselisihan. Para ulama seharusnya mengajarkan para santrinya untuk bisa berinteraksi secara harmonis di antara berbagai komunitas masyarakat Indonesia (Asy'ari, 1946).

Ilmu pengetahuan bagi Kiai Hasyim seharusnya diabdikan bagi kepentingan dan keselamatan bangsa Indonesia. Oleh karena itu, ia menghimbau komunitas Pesantren untuk mengajarkan santrinya memaksimalkan serta memanfaatkan seluruh potensi ekonomi dan sumber daya yang dimiliki oleh negara ini. Sehingga sangat wajar jika kemudian banyak pesantren yang muncul berdekatan dengan lokasi sumber-sumber mata air dan kekayaan alam (Baso et.al, 2017: 9-10).

\section{Persatuan Keagamaan dan Kebangsaan sebagai Pondasi Moderatisme}

Konsep Ahl al-Sunnah wa al-Jamaah ini selanjutnya dikembangkan oleh Kiai Hasyim dalam organisasi Nahdlatoel Oelama (NU) yang didirikannya pada 31 Januari 1926. Setelah NU berdiri, posisi golongan pesantren tradisional semakin menguat. Keinginan untuk mewujudkan negara Indonesia yang merdeka dan damai menjadi salah satu tujuan didirikannya organisasi ini, sebagaimana dinyatakan dalam Muktamar NU pada tahun 1936 di Banjarmasin (Baso et.al, 2017: 45). 
Kiai Hasyim menyadari bahwa untuk mewujudkan Indonesia yang damai diperlukan adanya persatuan, saling menghormati, dan menghargai, persaudaraan, dan toleransi, sebagaimana yang diajarkan dalam QS. alBaqarah: 213, Al-Ma'idah, 8, al-Anbiya: 107, dan al-Syura: 15. Petunjuk alQuran inilah yang selanjutnya mendorong Kiai Hasyim untuk menegaskan pentingnya menerapkan empat prinsip bermasyarakat yang harus dipedomani oleh warga NU: Pertama, tawasuth dan itidal, yaitu sikap tengah yang berintikan pada prinsip hidup yang menjunjung tinggi moderatisme beragama, menghindari segala bentuk rigiditas dan ekstrimisme dalam mengimplementasikan ajaran-ajaran agama, dan keharusan berlaku adil dan lurus di tengah-tengah kehidupan bersama.

Kedua, tasamuh, yaitu sikap toleran terhadap perbedaan pandangan baik dalam masalah keagamaan, terutama hal-hal yang bersifat cabang ( $\left.f u r u^{\prime}\right)$, atau menjadi masalah khilafiyah; serta dalam masalah kemasyarakatan dan kebudayaan. Ketiga, Tawazun, yakni sikap seimbang dalam berkhidmah. Menyerasikan khidmah kepada Allah Swt., khidmah kepada sesama manusia, serta kepada lingkungan hidupnya. Menyelaraskan kepentingan masa lalu, masa kini dan masa mendatang. Keempat, amar ma'ruf nahy munkar, yakni selalu memiliki kepekaan untuk mendorong perbuatan baik, berguna dan bermanfaat bagi kehidupan bersama; serta menolak da mencegah semua hal yang menjerumuskan dan merendahkan nilai-nilai kehidupan (Asy'ari, 2011a: 115-116).

Dalam bukunya, Risalah Ahl al-Sunnah wa al-Jama'ah, Kiai Hasyim kembali menuturkan pentingnya bersikap moderat dalam beragama. Ia tampak tidak setuju dengan ajaran Wahabi yang melarang berziarah ke makam Rasulullah Saw. Demikian pula, ia tidak sepakat dengan paham Syi'ah yang terlalu mengkultuskan keluarga (Ahl al-Bait) Rasulullah Saw., dan pada saat yang sama, mereka juga tidak segan mencela sahabat Rasulullah Saw. yang lain (Asy'ari, 2011b: 12-22). Ini dikarenakan bagi Kiai Hasyim, menghormati dan memuliakan keluarga Rasulullah Saw. sebagaimana dinyatakan dalam hadishadis beliau tidaklah dilakukan dengan cara berlebihan mengkultuskan mereka.

Kiai Hasyim juga mengajak untuk menjunjung tinggi nilai-nilai maupun norma-norma ajaran Islam, mendahulukan kepentingan bersama daripada kepentingan pribadi, menjunjung tinggi sifat keikhlasan dalam berkhidmah dan berjuang, menjunjung tinggi ilmu pengetahuan dan ulama, selalu siap untuk menyesuaikan diri dengan setiap perubahan yang membawa manfaat 
bagi kemaslahatan manusia, mengedepankan persatuan (Ittihad), persaudaraan (Ukhuwwah), dan kasih sayang. Selain itu, Kiai Hasyim juga menekankan pentingnya akhlak yang mulia, kejujuran dalam berfikir, bersikap dan berperilaku, serta menanamkan kesetiaan atau loyalitas kepada agama, bangsa, dan negara (Asy'ari, 2011a: 117-118).

Dari uraian tersebut, tampak pemikiran keagamaan dan kebangsaan Kiai Hasyim yang sejatinya bertumpu pada sikap moderatisme. Dengan berpijak dari al-Quran dan Hadis Nabi Saw., Kiai Hasyim menekankan pentingnya persatuan, persaudaraan, dan toleransi. Selanjutnya, dengan ketiga pilar ini, Kiai Hasyim berharap dapat melahirkan sikap-sikap keberagamaan yang moderat, terutama dalam konteks negara yang menganut kebinekaan dan demokrasi, maka sikap moderat menjadi suatu keniscayaan.

Persatuan dalam perspektif Kiai Hasyim dapat dibedakan menjadi dua jenis: Pertama, persatuan keagamaan, yaitu persatuan yang dilandasi kesamaan agama. Melalui organisasi yang didirikannya, Kiai Hasyim ingin menghimpun dan membangkitkan para kiai/ulama yang selama ini berjuang sendiri-sendiri. Karena perjuangan yang dilakukan secara terpisah rentan dengan kekalahan dan mudah disulut perselisihan dan perpecahan. Ia mengawali kebangkitan dari menghimpun para ulama, untuk kemudian diikuti oleh kebangkitan umat dan masyarakat muslim. Ketika masyarakat muslim bersatu maka akan menjadi kekuatan besar dalam memperjuangkan kemerdekaan dan mempertahankan Negara Kesatuan Republik Indonesia (NKRI) (Nizar, n.d.: 67-68).

Meski banyak bergaul dengan para pemikir reformis tatkala menuntut ilmu di Makkah, namun basis kultural dalam berdakwah tetap dipegangi oleh Kiai Hasyim. Baginya, tradisi lokal yang telah ada dan berkembang dalam komunitas masyarakat Indonesia tidak harus dihilangkan secara total melainkan menjadikan tradisi tersebut sebagai salah satu media dakwah dengan cara mengisi budaya tersebut dengan nilai-nilai keislaman dan menginternalisasikannya. Demikian pula dengan tradisi pesantren yang telah mapan digunakan Kiai Hasyim sebagai basis kultural medan dalam berdakwah. Hal ini menunjukkan bahwa Kiai Hasyim lebih mengedepankan persatuan keagamaan dalam mengusung misi dakwahnya.

Jika dicermati, model dakwah Kiai Hasyim memiliki kemiripan dengan cara dakwah para Walisanga tatkala mengenalkan Islam pertama kali kepada masyarakat Indonesia (Kasdi, 2017: 15-19). Mereka tidak menghilangkan 
lokalitas budaya Indonesia melainkan mengakomodirnya dengan memasukkan nilai-nilai Islam di dalamnya (Farida, 2015: 143). Sikap permisif dan akomodatif Walisanga yang diadopsi oleh Kiai Hasyim terhadap tradisitradisi lokal inilah yang menjadikan dakwah Kiai Hasyim mudah diterima oleh banyak kalangan masyarakat.

Kiai Hasyim mengembangkan Islam moderat yang bersifat kultural. Sifat kultural ini bisa terbentuk karena penekanan Kiai Hasyim atas substansi Islam. Budaya lokal diadaptasi secara selektif. Islam tidak hanya cocok diterima dan dipeluk oleh orang Indonesia saja, tetapi juga pantas mewarnai budaya Indonesia.

Kedua, persatuan kebangsaan, yaitu persatuan yang dilandasi dengan kesamaan kebangsaan. Keislaman dan keindonesiaan merupakan dua hal yang tidak bisa terpisah satu sama lain. Sejak masa perjuangan melawan penjajah, para ulama dan santri bersama elemen bangsa yang lain turut aktif memperjuangkan kemerdekaan.

Pemikiran Kiai Hasyim tentang persatuan kebangsaan diimplementasikan dalam kehidupan nyata. Kiai Hasyim turut berjuang dalam melawan hegemoni kolonial Belanda dan Jepang. Bahkan, ketika Jenderal Sudirman dan Bung Tomo mengirimkan utusan yang menyampaikan saran agar Kiai Hasyim mengungsi untuk menghindari serangan Jepang, maka Kiai Hasyim menolak saran tersebut dan memilih untuk tetap berjuang dan berperang bersama para santrinya yang belajar di Pesantren Tebuireng. Ini merupakan wujud nyata dari implementasi pemikiran bahwa persatuan dalam semangat nasionalisme yang diupayakan secara maksimal oleh Kiai Hasyim.

Mempertahankan negara dan mewujudkan persatuan kebangsaan merupakan suatu keniscayaan. Indonesia adalah daerah Islam (Dar al-Islam) karena itu mempertahankan NKRI merupakan perwujudan dari upaya umat Islam Indonesia untuk menjalankan syariat Islam (Bizawie, 2016b: 4). Status Dar al-Islam ini tidak akan berubah menjadi Dar al-Harb apabila orang Islam yang menetap di dalamnya tidak dihalangi untuk melaksanakan syariat agamanya. Akan tetapi, jika negara tersebut dikuasai oleh pemimpin nonMuslim dan menghalangi umat Islam untuk melaksanakan ajaran agamanya, maka statusnya berubah menjadi Dar al-Harb. Senada dengan ini, Kacung Marijan dalam tulisannya "Nasionalisme NU dan Politik Kebangsaan" sebagaimana dikutip Bizawie (2016a: xxix-xxxi) mengungkapkan bahwa Kiai Hasyim bersama para kiai dan santri yang terhimpun dalam NU memiliki peran 
dan jasa besar dalam merebut kemerdekaan Indonesia. Hal ini bisa dilihat dari perjuangan yang diperankan oleh para kiai NU generasi awal dalam mengusir penjajah. Didirikannya NU selain untuk mempertahankan dan mengembangkan tradisi atau paham Islam Ahl al-Sunnah wa al-Jama'ah, juga penuh semangat kebangsaan. Oleh karenanya, tidak berlebihan jika Kiai Hasyim disebut sebagai tokoh penggerak nasionalisme. Ia menegaskan bahwa persatuan keislaman harus bersinergi dengan persatuan kebangsaan. Rasa kebangsaan Kiai Hasyim tumbuh dan dilandasi nilai-nilai keagamaan pesantren. Inilah yang membedakan nasionalisme Kiai Hasyim dengan nasionalisme sekuler.

Nasionalisme Kiai Hasyim terlihat nyata saat menyerukan Resolusi Jihad pada pertempuran melawan penjajah pada 22 Oktober 1945. Perintah untuk membela negara dari serangan penjajah dalam Resolusi tersebut berisi tiga poin penting, yaitu: Pertama: bahwa kewajiban mempertahankan negara bersifat fardlu 'ain, yakni kewajiban setiap individu yang mampu (mukallaf) untuk melaksanakannya. Kedua, perang melawan penjajah merupakan bentuk perjuangan di jalan Allah (jihad fi sabilillah), dan oleh karena itu kaum muslim yang gugur dalam peperangan tersebut masuk dalam kategori syahid. Ketiga, siapapun yang mengkhianati dan menodai perjuangan kaum muslim dengan mengadu domba, memecah-belah persatuan dan membantu penjajah, maka hukumnya wajib untuk dibunuh.

Kiai Hasyim juga turun langsung memimpin pertempuran dengan menjadi komandan spiritual laskar Hizbullah. Sejarah mencatat bahwa setelah munculnya Resolusi Jihad, maka para kiai dan santri bergerak dan berjuangan dalam pertempuran 10 November 1945 sekaligus merupakan momen kekalahan pasukan sekutu yang tidak pernah diduga sebelumnya. Ini dikarenakan, bagi Kiai Hasyim, mempertahankan NKRI dari segala ancaman wajib dilakukan oleh kaum muslim, bukan semata-mata atas nama nasionalisme semata, melainkan dalam rangka menjamin keamanan umat Islam yang tinggal di negara tersebut untuk dapat menjalankan perintah agamanya. Fatwa jihad Kiai Hasyim ini ditegaskan kembali dalam ceramahnya yang disampaikan pada Muktamar NU ke-XVI di Purwekerto pada 26-29 Maret 1946.

Meskipun jasa dan perjuangan besar sudah dilakukan Kiai Hasyim dalam mewujudkan Indonesia merdeka, nilai persatuan dan pertimbangan kemaslahatan bangsa tetap dikedepankan. Hal ini ditunjukkan melalui 
persetujuan Kiai Hasyim terkait bentuk negara Republik Indonesia yang tidak didasarkan pada agama tertentu, yang dinilai oleh Lahiful Khuluq (1998: 4167), sebagai perilaku moderat dan toleransi yang tinggi.

\section{Kontribusi Kiai Hasyim dalam Membangun Moderasi Beragama Berlandaskan al-Qur'an dan Hadis}

Usaha Kiai Hayim dalam menumbuhkan sikap moderatisme beragama, bermula dari persatuan sebagaimana telah terurai di atas selanjutnya dikembangkan menjadi persaudaraan. Kiai Hasyim (n.d.: 23-26) menjelaskan dalam bukunya al-Tibyan fi al-Nahy 'an Muqatha'ah al-Arham wa al-Aqarib wa al-Ikhwan, bahwa kedudukan persaudaraan dalam Islam adalah penting karena akan menjadi pondasi yang kokoh dalam tatanan sebuah masyarakat. Sebuah masyarakat dan bangsa yang jaya tidak akan terbentuk apabila di dalamnya tidak ada semangat kebersamaan, persaudaraan, dan gotong royong.

Bagi Kiai Hasyim, persaudaraan adalah landasan moderasi yang sangat menghargai kemanusiaan. Pada saat yang sama, persaudaraan juga menjadi basis demokrasi yang telah dikenalkan sejak awal perkembangan Islam. Persaudaraan ini menjadi penting karena dengan adanya persaudaraan, maka akan hilang kezaliman dan ketidakadilan dalam masyarakat (Khuluq, 2000: 45).

Landasan teologis Kiai Hasyim dalam membangun persaudaraan adalah QS. al-Baqarah: 27; al-Nisa: 1; Muhammad: 22. Ia juga merujuk pada hadishadis Rasulullah Saw. yang menegaskan pentingnya menyambung persaudaraan dan silaturrahim, bahkan dimulai dari lingkungan keluarga. Jika kultur persatuan dan persaudaraan dapat tumbuh dengan baik dalam lingkungan keluarga, maka persaudaraan dalam konteks yang lebih luas akan tercapai, baik dalam konteks internal agama maupun antaragama dalam lingkup negara-bangsa. Oleh karenanya, menurut Zuhairi Misrawi (2013: 252253), nilai persatuan dan persaudaraan yang diajarkan Kiai Hasyim perlu untuk dihidupkan kembali, terutama dalam konteks mendorong agar agama memiliki korelasi positif dengan spirit kebangsaan dan keharmonisan. Agama harus menjadikan seseorang semakin mengerti betapa pentingnya persatuan dan persaudaraan sebagai salah satu prasyarat terciptanya ikatan-ikatan sosial yang kuat, produktif, dan kreatif.

Bagai Kiai Hasyim oleransi juga merupakan sebuah keniscayaan bagi masyarakat yang majemuk. Toleransi baik sebagai paham maupun sikap hidup 
seharusnya memberikan nilai positif untuk kehidupan masyarakat yang saling menghormati dan menghargai perbedaan agama dan keragaman tersebut. Dalam pandangan Kiai Hasyim, toleransi menemukan relevansinya dalam ajaran agama Islama sebagaimana yang dinyatakan Rasulullah Saw. dalam hadis bahwa agama yang paling dicintai oleh Allah adalah agama yang lurus dan toleran (Al-Bukhari, 2004: 1: 68). Demikian juga sesuai dengan QS. AlHujurat: 13, al-Nahl: 125, Ali Imran: 200. Oleh karena itu, manusia sebagai makhluk sosial yang tidak dapat hidup tanpa manusia lain maka perlu membangun toleransi untuk menghindari perpecahan.

Perjuangan untuk membangun toleransi sejatinya merupakan perjuangan eksistensial. Ini dikarenakan apabila sebuah masyarakat semakin toleran, maka akan memudahkan pembangunan masyarakat yang damai dan maju. Sebaliknya, jika masyarakat tidak toleran, maka masyarakat rentan mengalami perselisihan dan kemunduran. Kiai Hasyim menyadari bahwa perbedaan pandangan keagamaan, khususnya masalah-masalah khilafiyah dapat menimbulkan perpecahan dan menyebabkan hilangnya persaudaraan dan toleransi. Perbedaan dalam ijtihad hukum Islam, sebagaimana disampaikan ulama terdahulu, merupakan jembatan emas bagi siapapun yang melaksanakannya. Jika benar, akan mendapatkan dua pahala, dan jika salah pun, mendapatkan satu pahala.

Toleransi juga bermanfaat untuk mengubur berbagai kebencian dan kecurigaan, terutama yang berbasis paham keagamaan. Di sini, semangat kebangsaan dapat membangun sikap saling percaya diri, baik kelompok mayoritas maupun minoritas. Apapun agama, paham keagamaan, dan golongannya, mereka berada dalam satu payung bangsa (Misrawi, 2013: 263).

Perbedaan pemikiran keagamaan dalam masyarakat Indonesia memang sesuatu yang niscaya tetapi tidak untuk saling menafikan. Sikap saling menghormati dan toleransi perlu terus dikembangkan. Djaelani (1994: 93-94) mencatat pidato Kiai Hasyim tentang pentingnya toleransi dan menjaga persaudaraan sebagai berikut: "Wahai Ulama, jika engkau melihat orang berbuat sesuatu berdasarkan kepada qaul para Imam yang boleh ditaklidi, meskipun qaul itu tidak memiliki dasar argumen yang kuat, maka apabila engkau tidak setuju maka janganlah engkau cerca mereka, tetapi berilah petunjuk dengan lemah lembut! Dan jika mereka tidak mau mengikutimu, janganlah mereka dimusuhi. Jika engkau berbuat demikian, maka samalah engkau dengan orang yang membangun istana, dengan menghancurkan terlebih dahulu sebuah kota. Janganlah engkau menjadikan semua hal itu 
menjadi penyebab perpecahan, menjadikan umat bercerai-berai, saling bertengkar dan bermusuhan. Padahal agama kita hanyalah satu belaka, yaitu Islam!"

Bizawie (2016a: 201) menambahkan, bahwa pidato Kiai Hasyim ini selanjutnya menuai respons positif dari para tokoh Islam seperti KH. Mas Mansur (Muhammadiyah), KH. Wahab Hasbullah, W. Wondomiseno (PSII) dan perwakilan organisasi Islam lainnya untuk membentuk sebuah wadah bersama umat Islam Indonesia berupa federasi organisasi Islam di Hindia Belanda yang dinamakan Majelis Islam A'la Indonesia (MIAI).

Senada dengan pidato di atas, Syihab (1994) juga mendokumentasikan statemen Kiai Hasyim yang meneguhkan pentingnya moderasi dan sikap saling menghormati, "Bagaimana bisa umat Islam berpecah belah, sedang kitab mereka al-Qur'an adalah satu, Nabi mereka Nabi Muhammad Saw. adalah satu, kiblat mereka Ka'bah adalah satu. Tidak ada sesuatu yang patut dijadikan alasan mereka berpecah-belah, apalagi sampai saling mengkafirkan satu sama lain."

Statemen Kiai Hasyim semakin meneguhkan bahwa persaudaraan dan toleransi merupakan nilai yang seharusnya mendarah-daging dalam diri setiap muslim (Asy'ari, 1996: 36-37). Keduanya merupakan sesuatu yang sangat esensial karena akan menjadi prasyarat untuk membentuk masyarakat dan bangsa yang kuat. Khazanah tersebut diharapkan dapat memperkuat bangunan moderasi, yang pada akhirnya akan memperkuat bangunan mioderasi, yang pada akhirnya akan memperkuat bangunan demokrasi di negara Indonesia ini (Misrawi, 2013: 271).

Mukani (2018:133) menyuguhkan salah satu bukti toleransi Kiai Hasyim ketika berkenan dimintai tolong untuk mendoakan dan mengobati salah satu pegawai Belanda yang notabene non-Muslim pada saat para dokter dan tabib tradisional pada saat itu tidak mampu mengobati anak si pegawai tersebut. Kiai Hasyim berkenan mengobati yang lambat laut menggerakkan hati si pegawai beserta keluarganya untuk masuk Islam. Jadi, Kiai Hasyim telah meletakkan dasar-dasar moderasi beragama tidak hanya terbatas dalam pemikiran keagamaannya, tetapi juga mewujud dalam sikap keberagamaannya yang ia terapkan dalam kehidupan kesehariannya juga melalui pendidikan keagamaan di pesantren Tebuireng ataupun dalam organisasi massa NU yang didirikannya, dimana pengikutnya hingga sekarang mempunyai komitmen yang kuat terhadap toleransi. 
Moderatisme Kiai Hasyim dalam pemikiran dan sikap keberagamaannya memberikan inspirasi kepada para ulama dan tokoh Islam berikutnya untuk berada dalam sikap pertengahan, seimbang, dan moderat. KH. Machfudz Shiddiq misalnya, juga menekankan sikap moderat bahkan termasuk dalam hal aqidah, yakni dengan menyeimbangkan penggunaan pemikiran rasional dan dalil-dalil teks al-Qur'an dan Hadis. Keseimbangan ini dapat dicapai dengan menjaga keaslian doktrin Islam dari pengaruh-pengaruh luar-dan pada saat yang sama-dengan menghindarkan diri secara gegabah dari mengklaim saudara Muslim yang lain sebagai kafir. Bahkan sekalipun saudaranya itu belum mampu memurnikan kepercayaan mereka (Shiddiq, 1979: 41)(Solikhin, 2016: 353).

Demikian pula dengan Nurcholis Madjid (2000: 602-604) yang berpandangan bahwa moderatisme Kiai Hasyim lebih menunjukkan kepada sebuah kesadaran di antara masyarakat muslim untuk menghormati eksistensi masyarakat lain. Pemikiran Kiai Hasyim tentang moderasi beragama telah mendorong masyarakat muslim untuk bersikap adil kepada masyarakat lain atas dasar perdamaian dan saling menghormati. Pemikiran Kiai Hasyim ini sangat relevan untuk kembali dihidupkan terutama pada masa sekarang dimana Indonesia sering kali dihadapkan pada konflik antar umat beragama.

\section{Simpulan}

Kiai Hasyim yang dikenal sebagai pengasuh Pesantren Tebuireng dan pendiri organisasi Nahdlatul Ulama telah mengabdikan dirinya untuk kepentingan umat Islam dan bangsa Indonesia. Ia merupakan pendidik dan pendakwah Islam yang terkenal dengan kelembutan dan kesantunannya. Ia tidak mempertentangkan antara ajaran Islam dengan budaya masyarakat Indonesia. Ia juga berperan aktif dalam memperjuangkan kemerdekaan Indonesia dengan turut angkat senjata bersama para santrinya dan menyerukan revolusi jihad melawan imperialisme Belanda dan Jepang.

Kontribusi Kiai Hasyim tidak hanya tampak sebagai pelopor perdamaian dan penjaga kearifan Nusantara saja, melainkan juga gigih menyerukan moderasi beragama. Terlebih Indonesia sebagai negara majemuk dan beragam agama yang berbeda menjadikan sikap moderat antara masing-masing pemeluk agama menjadi suatu keniscayaan. Kiai Hasyim melandaskan pentingnya moderasi beragama dari al-Qur'an dan Hadis Rasulullah Saw., dan menjadikan tiga hal yakni persatuan, persaudaraan, dan toleransi sebagai pilar 
moderasi beragama yang perlu dikembangkan dalam merawat kemajemukan bangsa Indonesia.

\section{Referensi}

Abu Dawud, S. ibn al-A. (2005). Sunan. Beirut: Dar al-Kutub al-Ilmiyah.

Al-Bukhari, M. I. B. (2004). Shahih al-Bukhari. Cairo: Dar al-Hadits.

Al-Tirmizi, A. I. M. ibn I. (2006). Sunan. Beirut: Dar al-Fikr.

Asy'ari, H. (1996). Al-Tanbihat wal Wajibat. Jombang: Maktabah al-Turas al-Islami.

Asy'ari, H. (1946). Naskah Pidato dalam Muktamar Masyumi pertama di Solo pada 13 Februari 1946. Retrieved from https://www.nu.or.id/post/read/104232/pidatolengkap-kh-hasyim-asyari-tentang-ideologi-politik-islam

Asy'ari, H. (2011a). Qanun Asasi. Jombang: Maktabah al-Turas al-Islami.

Asy'ari, H. (2011b). Risalah Ahl al-Sunnah wa al-Jama'ah. Jakarta: LTN PBNU.

Asy'ari, H. (n.d.). Al-Tibyan fi al-Nahy 'an Muqatha'ah al-Arham wa al-Aqarib wa alIkhwan, Jombang: Maktabah al-Turas al-Islami.

Baso et.al, A. (2017). KH. Hasyim Asy'ari: Pengabdian Seorang Kiyai untuk Negeri. Jakarta: Museum Kebangkitan Nasional.

Bizawie, Z. M. (2016a). Laskar Ulama-Santri \& Resolusi Jihad: Garda Depan Menegakkan Indonesia. Jakarta: Pustaka Compass.

Bizawie, Z. M. (2016b). Masterpiece Islam Nusantara; Sanad dan Jejaring UlamaSantri 1830-1945. Jakarta: Pustaka Compass.

Burhanuddin, J. (2011). Ulama dan Kekuasaan. Bandung: Mizan.

Dhofier, Z. (1994). Tradisi Pesantren: Studi Pandangan Hidup Kyai dan Visinya Mengenai Masa Depan Indonesia. Jakarta: LP3ES.

Djaelani, A. Q. (1994). Peran Ulama dan Santri dalam Perjuangan Politik Islam di Indonesia. Surabaya: Bina Ilmu.

Farida, U. (2015). Islam Pribumi dan Islam Puritan: Ikhtiar Menemukan Wajah Islam Indonesia Berdasar Proses Dialektika Pemeluknya dengan Tradisi Lokal. Jurnal Fikrah, 3(1), 141-156.

Hadzik, I. (2000). KH. Hasyim Asy'ari: Figur Ulama dan Pejuang Sejati. Surabaya: Litera Perkasa.

Harahap, S. (2011). Teologi Kerukunan. Jakarta: Prenada Media.

Kasdi, A. (2017). The Role of Walisongo in Developing Islam Nusantara Civilization. Jurnal Addin, 11(1), 1-26. https://doi.org/10.21043/addin.v11i1.1973

Kasdi, A. (2019). Wasathiyyah Islam as The Road to Moderatism in Indonesia. AlAlbab, 8(2), 179-192. https://doi.org/10.24260/alalbab.v8i2.1356 
Kasdi, A., Farida, U., \& Mahfud, C. (2020). Islamic Studies and Local Wisdom at PTKIN in Central Java: Opportunities, Challenges, and Prospects of Pioneering Religious Moderation in Indonesia. Hikmatuna, 6(1), 51-62. https://doi.org/10.28918/hikmatuna.v6i1.2618

Khuluq, L. (1998). KH. Hasyim Asy'ari Contribution to Indonesian Independence. Jurnal Studia Islamica, (1), 41-67.

Khuluq, L. (2000). Fajar Kebangunan Ulama: Biografi KH. Hasyim Asy'ari. Yogyakarta: LKiS.

Madjid, N. (2000). Islam, Doktrin dan Peradaban (IV). Jakarta: Paramadina.

Misrawi, Z. (2013). Hadratussyaikh Hasyim Asy'ari: Moderasi, Keumatan, dan Kebangsaan. Jakarta: Kompas.

Mukani. (2018). Toleransi Perspektif KH. M. Hasyim Asy'ari dan Peran Pendidikan Islam Sebagai Upaya Deradikalisasi di Indonesia. Jurnal Al-Murabbi, 4(2), 121142.

Nizar, M. C. (n.d.). Pemikiran KH. Hasyim Asy'ari tentang Persatuan. Endogami: Jurnal Ilmiah Kajian Antropologi, 63-74.

Salam, S. (1966). KH. Hasyim Asy'ari Ulama Besar Indonesia. Jakarta: Jaya Murni.

Shiddiq, M. (1979). Ijtihad dan Taqlid dalam Ahlussunnah Waljama'ah. Surabaya: LP. Ma'arif Jawa Timur.

Solikhin, M. (2016). Gerakan Pemikiran dan Peran Tiga Ulama NU dalam Menegakkan Ahl Al-Sunnah Wal-Jamā'ah Al-Nahḍiyyah Di Jawa Tahun 1926-1971: Kajian Terhadap Pemikiran K.H. Hasyim Asy'ari, K.H.R. Asnawi, K.H. Wahhab Hasbullah. Jurnal Theologia, 27(2), 331-364.

Syihab, M. A. (1994). Hadratussyaikh Muhammad Hasyim Asy'ari: Perintis Kemerdekaan Indonesia. Yogyakarta: Titian Ilahi Press. 